\title{
HEPATO- AND NEPHROTOXICITY IN MALE ALBINO RATS EXPOSED TO MALATHION AND SPINOSAD IN STORED WHEAT GRAINS
}

\author{
NOUR EL-HODA A. ZIDAN* \\ Pesticides Chemistry and Toxicology Department, Faculty of Agriculture, Kafrelsheikh University, \\ 33516 Kafr El-Sheikh, Egypt
}

(Received: September 4, 2014; accepted: September 29, 2014)

\begin{abstract}
Adult male albino rats were fed on stored wheat grains (Triticum aestivum L.) treated with malathion and spinosad at both 8 and $16 \mathrm{ppm}$ for 90 consecutive days to evaluate their hepatic and renal toxicity. The activity of serum acetylcholinesterase (AChE) was decreased in rats treated with the higher concentration of both tested pesticides. Biochemical parameters of liver functions [i.e., aspartate aminotransferase (AST), alanine aminotransferase (ALT), alkaline phosphatase (ALP), acid phosphatase (ACP) activity, as well as total protein, albumin, bilirubin and cholesterol levels] were severely affected especially at higher concentration. Malathion and spinosad elevated the activity of ALT, AST, ALP and ACP in rats treated with the higher concentration. Also, total and direct bilirubin levels increased in rats treated with the higher concentration of both pesticides. On the contrary, both pesticides decreased total protein and albumin levels in treated rats in a concentration-dependent manner. Furthermore, malathion was found to be hyperglycemic. Kidney function parameters (i.e., urea and creatinine levels) were increased in treated rats in a concentration-dependent manner. The above mentioned effects were supported by histopathological examination of liver and kidney tissues. The obtained results indicated also that malathion was able to cause a more pronounced hepato- and renal toxicity in rats than spinosad.
\end{abstract}

Keywords: Pesticide - rat - liver - kidney - biochemical parameters - histopathology

\section{INTRODUCTION}

The consumer's demand for residue-free food and the need for re-registration of several widely used pesticides in stored grain protection have led researchers to the evaluation of reduced-risk pesticides that pose a lower health risk to humans and the environment. One of the conventional neurotoxic insecticides which are used as grain protectants, the organophosphorus compound, is malathion. Malathion is one of the top 10 active ingredients used in agriculture worldwide [20]. It is recognized for its ability to induce toxicity through inhibition of acetylcholinesterase (AChE), leading to accumulation of synaptic ACh levels with persistent/prolonged activation of cholinergic receptors on postsynaptic cells. This relative increase in cholinergic signaling

\footnotetext{
*E-mail address: nourelhoda_az@yahoo.com
} 
leads to functional signs and symptoms of cholinergic toxicity [12]. Malathion remains a commonly used grain protectant in Egypt and throughout the world, though it is well established that many populations of the common stored grain insects have evolved resistance to this compound [2]. It has been the stored grain insecticide of choice in different countries due to its high toxicity to a wide range of stored product pests and its relatively low mammalian toxicity [18]. On the other hand, the increasing resistance of many stored product pests to this pesticide has resulted in the need for alternative control agents. One of the most promising alternatives to this traditional pesticide in stored grains is the use of spinosad, which is a metabolite of the actinomycete Saccharopolyspora spinosa Mertz and Yao [40]. Spinosad is characterized by excitation of the nervous system, leading to involuntary muscle contractions, prostration with tremors, and paralysis. These effects are consistent with the activation of nicotinic acetylcholine receptors by a mechanism that is clearly novel and unique among known insect control products. Spinosad also has effects on GABA receptor function that may contribute further to its insect activity [35].

Spinosad has received U.S. Environmental Protection Agency approval for its use as a grain protectant in 2005 [39], as an alternative to traditional grain protectants because it has low mammalian toxicity. Since then, spinosad has been shown to provide highly effective and long-lasting control of numerous key stored product pests on various grains [14, 41, 47, 48]. Zidan and Galal [49] found that malathion and spinosad residues in stored wheat grains had potential hematological and cytogenetical effects on male albino rats, so these findings opened the door for further studies examining the potential toxicological effects of spinosad on health. The wide selectivity of spinosad among insects and non-target organisms is not fully understood. The acute oral $\mathrm{LD}_{50}$ values for this substance in rat ranged from 3738 to $45,000 \mathrm{mg}$ / $\mathrm{kg}$ body weight [45].

During literature review, little published studies related to subchronic effects of spinosad on hepatic and renal parameters in non-target organisms especially after grain treatment could be found. Keeping above facts in view, the present study was designed to evaluate the effect of sub-chronic exposure of male albino rats to malathion and spinosad on hepato- and renal toxicity.

\section{MATERIALS AND METHODS}

\section{Pesticides}

Malathion (Nasr lathion ${ }^{\circledR}, 1 \% \mathrm{WP}$ ) and spinosad (Tracers ${ }^{\circledR}, 24 \%$ SC) were provided by El-Nasr Chemical Industries Co., Egypt and Dow AgroSciences Company (USA), respectively. 


\section{Tested animals}

Adult male albino rats (Sprague-Dawley), Rattus norvegicus var. albus, weighting 160-185 g were purchased from the Biological Products \& Vaccines Holding Company, Helwan Farm, Cairo, Egypt. Rats were kept under the laboratory conditions of $25 \pm 5^{\circ} \mathrm{C}$ and $65 \pm 5 \%$ R.H. for two weeks as an acclimatization period. They were housed in metallic cages $(35 \times 25 \times 20 \mathrm{~cm})$ and maintained on ad libitum diet and water. Rats were sacrificed after feeding on stored wheat grains treated with two concentrations of both tested insecticides. All treatments and procedures were in accordance with the protocol of National's Animal Care and Use Committee, and Helsinki Declaration.

\section{Experimental design}

Rats used in this study were divided randomly into five groups, each of ten rats. The first group was fed on pesticides-free wheat diet and was considered as a control. The second and third groups were fed on wheat grains treated with $8 \mathrm{ppm}$ of malathion (according to the recommended concentration for stored-grain pest control by Egyptian Ministry of Agriculture and Land Reclamation) and 16 ppm (double of the recommended concentration). The fourth and fifth groups received wheat grains treated with 8 and $16 \mathrm{ppm}$ of spinosad (the most efficient concentrations used for stored-grain pest control, [47]). Pesticides-free wheat (Triticum aestivum L.) was used in preparing of the toxicated wheat grains diet as described by Eissa and Zidan [13]. Feeding administration lasted for 90 successive days.

\section{Blood samples}

At the end of this experiment (90 days), blood samples were individually collected from each rat, immediately after slaughtering in dry clean centrifuge tubes and left to clot at room temperature for about $20 \mathrm{~min}$ and then centrifuged at 4000 r.p.m. for 15 minutes, the supernated serum samples were divided into Eppendorf tubes and kept in deep freezer at $-20^{\circ} \mathrm{C}$ until conducting the biochemical analysis.

\section{Parameters studied}

\section{Signs of toxicity}

During the experimental period, rats were under observation for general appearance, behavior, symptoms of toxicity and mortality. Signs of toxicity were observed at least twice daily during the study. 


\section{Relative weights of male albino rat's liver and kidney}

At the end of the experimental period, liver and kidney from each sacrificed rat were dissected out, trimmed of excess fat and weighed (the relative weight of the organ equals the weight of the organ divided by the weight of whole rat body).

\section{Biochemical analysis}

Activities of some enzymes and concentrations of certain biochemical parameters representing liver and kidney functions were determined in the rats blood sera colorimetrically. The activities and levels of serum acetylcholinesterase (AChE), alanine aminotransferase (ALT), aspartate aminotransferase (AST), alkaline phosphatase (ALP), acid phosphatase (ACP), total protein, albumin, bilirubin, cholesterol, glucose, urea and creatinine were measured using reagent kits purchased from Diamond Diagnostics, Egypt.

\section{Histopathological study}

The influence of the tested pesticides on the histopathology of liver (the essential organ for drug metabolism) and kidney (the essential organ for drug excretion) was investigated as follows. The organs were fixed in $10 \%$ buffered formalin and were processed for paraffin sectioning by dehydration in different concentrations of alcohol, cleared with xylol and embedded in paraffin blocks. Sections of about $5 \mu \mathrm{m}$ thickness were stained with Harris haematoxylin and eosin (H\&E) for histopathological examination according to Lillie and Fullmen [23].

\section{Statistical analysis}

Statistical analysis was performed by one-way analysis of variance (ANOVA) followed by LSD tests using the computer program package SPSS; version 9.0 and the significance of difference was set up at $\mathrm{p}<0.05$.

\section{RESULTS}

\section{Physical observation}

No obvious signs of toxicity were noticed during the experimental period in the behavioral activity or external appearance in any of the treated rats at any of the tested concentrations. Furthermore, no mortality occurred. 


\section{Biochemical analysis}

Changes in pseudocholinesterase (PChE) activity

The results indicate that $\mathrm{PChE}$ activity in malathion- and spinosad-treated rats with the higher concentration (16 ppm) decreased significantly compared to the control group (Table 1).

Table 1

Serum AChE activity of male albino rats feeding for 90 days on wheat grains treated with two concentrations of malathion and spinosad

\begin{tabular}{|c|c|c|c|}
\hline \multirow{2}{*}{\multicolumn{2}{|c|}{ Treatment }} & \multicolumn{2}{|c|}{$\mathrm{PChE}$ (U/g protein) } \\
\hline & & \multirow{2}{*}{$\begin{array}{c}\text { activity } \\
4.01^{\mathrm{a}} \pm 0.490\end{array}$} & \multirow{2}{*}{$\begin{array}{c}\% \text { of contro } \\
87.93\end{array}$} \\
\hline & $8 \mathrm{ppm}$ & & \\
\hline Nialatmont & $16 \mathrm{ppm}$ & $2.85^{b} \pm 0.386$ & 62.50 \\
\hline \multirow{2}{*}{ Spinosad } & $8 \mathrm{ppm}$ & $4.25^{\mathrm{a}} \pm 0.258$ & 93.20 \\
\hline & $16 \mathrm{ppm}$ & $3.50^{\mathrm{b}} \pm 0.484$ & 76.75 \\
\hline \multicolumn{2}{|l|}{ Control } & $4.56^{a} \pm 0.264$ & 100.00 \\
\hline
\end{tabular}

Each value represents the mean of ten replicates.

Values across each column having the same superscript letters were not significantly different $(\mathrm{p}>0.05)$

\section{Changes in hepatic function parameters}

Data in Table 2 illustrate that malathion and spinosad elevated the activity of ALT, AST, ALP and ACP in rats treated with the higher concentration. Also, total bilirubin and direct bilirubin levels increased in rats treated with the higher concentration of both pesticides, while glucose concentration increased in rats treated with the higher concentration of malathion only (Table 3). On the contrary, malathion and spinosad decreased total protein and albumin concentrations in serum of treated rats in a concentration-dependent manner, whereas cholesterol concentration remained unaltered (Table 3).

\section{Changes in renal function parameters}

Results in Table 4 show that malathion and spinosad increased urea and creatinine levels in serum of treated rats in a dose-dependent manner. 

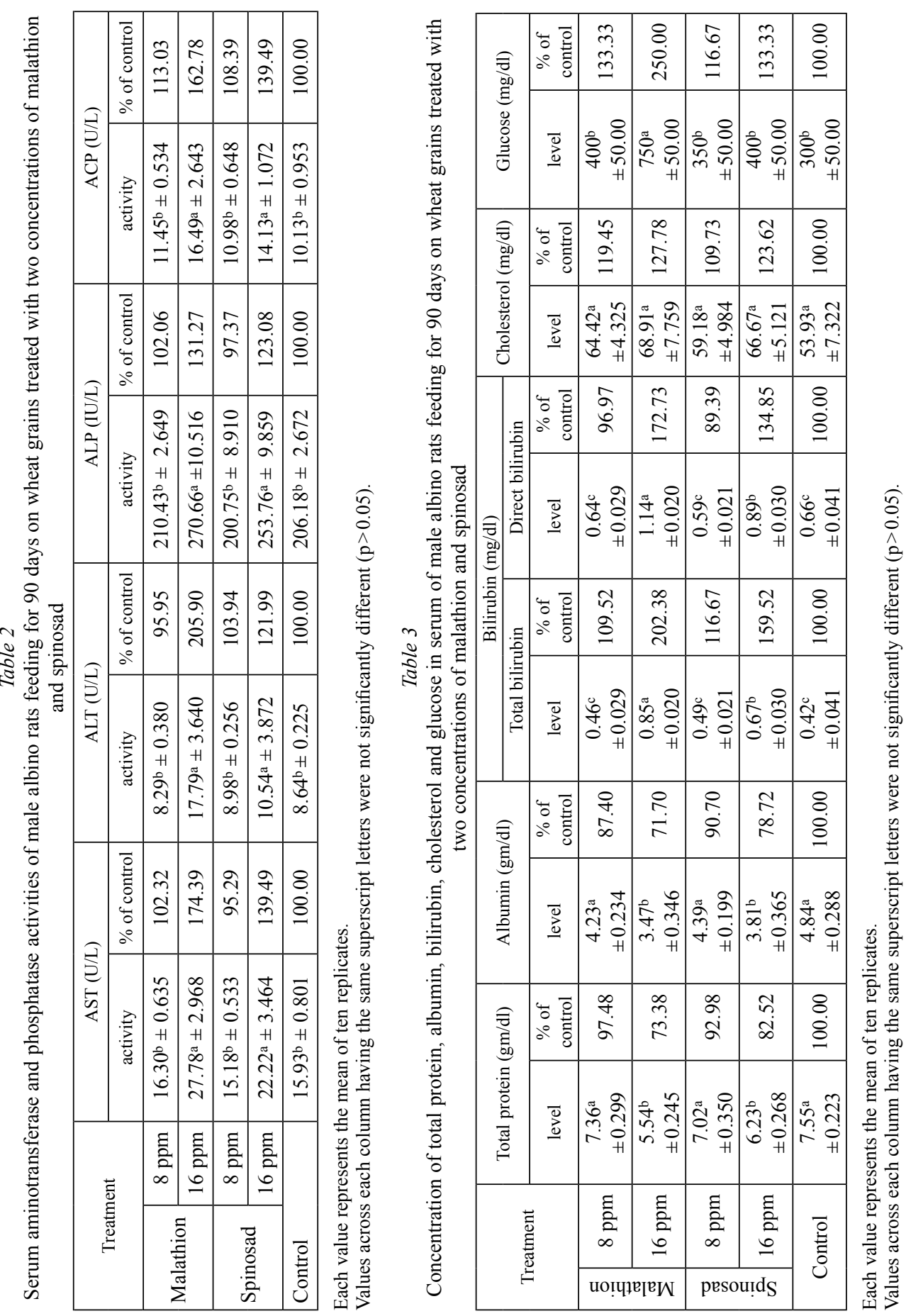


\section{Histopathological changes}

\section{Relative weights of male albino rat's liver and kidney}

Results in Table 5 indicate that administration of malathion and spinosad at the higher concentration resulted in a significant increase in the relative weight of treated male rat's liver in comparison with that of control rats. On the other hand, both pesticides exhibited no significant alteration in the relative weight of kidney of treated male rats in comparison with that of control rats.

\section{Histopathological changes in the liver and kidney}

As shown in details in Figs 1 and 2, no histopathological changes were observed in the specimens collected from the control rat liver and kidney which exhibited a normal

Table 4

Concentration of uric acid and creatinine in serum of male albino rats feeding for 90 days on wheat grains treated with two concentrations of malathion and spinosad

\begin{tabular}{|l|c|c|c|c|c|}
\hline \multicolumn{2}{|c|}{ Treatment } & \multicolumn{2}{c|}{ Urea (mg/dl) } & \multicolumn{2}{c|}{ Creatinine (mg/dl) } \\
\cline { 3 - 6 } & level & \% of control & level & $\%$ of control \\
\hline \multirow{3}{*}{ Malathion } & $8 \mathrm{ppm}$ & $17.76^{\mathrm{c}} \pm 1.472$ & 95.18 & $0.789^{\mathrm{b}} \pm 0.138$ & 104.09 \\
\cline { 2 - 6 } & $16 \mathrm{ppm}$ & $31.75^{\mathrm{a}} \pm 2.435$ & 170.15 & $1.450^{\mathrm{a}} \pm 0.037$ & 191.29 \\
\hline \multirow{3}{*}{ Spinosad } & $8 \mathrm{ppm}$ & $18.13^{\mathrm{c}} \pm 1.794$ & 97.16 & $0.714^{\mathrm{b}} \pm 0.098$ & 94.20 \\
\cline { 2 - 6 } & $16 \mathrm{ppm}$ & $25.13^{\mathrm{b}} \pm 2.018$ & 134.67 & $1.140^{\mathrm{a}} \pm 0.054$ & 150.40 \\
\hline Control & $18.66^{\mathrm{c}} \pm 1.093$ & 100.00 & $0.758^{\mathrm{b}} \pm 0.117$ & 100.00 \\
\hline
\end{tabular}

Each value represents the mean of ten replicates.

Values across each column having the same superscript letters were not significantly different $(p>0.05)$.

Table 5

Relative weights of liver and kidney of male albino rats feeding for 90 days on wheat grains treated with two concentrations of malathion and spinosad

\begin{tabular}{|l|c|c|c|c|c|}
\hline \multirow{2}{*}{\multicolumn{2}{|c|}{ Treatment }} & \multicolumn{3}{|c|}{ Mean relative weight (gm organ/100 gm b.w.) } \\
\cline { 3 - 6 } \multicolumn{2}{|c|}{} & \multicolumn{2}{|c|}{ Liver } & \multicolumn{2}{c|}{ Kidney } \\
\cline { 3 - 6 } \multicolumn{2}{|c|}{} & Mean & \% of control & Mean & $\%$ of control \\
\hline \multirow{3}{*}{ Malathion } & $8 \mathrm{ppm}$ & $6.12^{\mathrm{b}} \pm 0.231$ & 106.62 & $3.45^{\mathrm{a}} \pm 0.184$ & 91.76 \\
\cline { 2 - 6 } & $16 \mathrm{ppm}$ & $7.99^{\mathrm{a}} \pm 0.259$ & 139.20 & $3.49^{\mathrm{a}} \pm 0.169$ & 92.82 \\
\hline \multirow{2}{*}{ Spinosad } & $8 \mathrm{ppm}$ & $6.03^{\mathrm{b}} \pm 0.210$ & 105.05 & $3.39^{\mathrm{a}} \pm 0.192$ & 90.16 \\
\cline { 2 - 6 } & $16 \mathrm{ppm}$ & $7.72^{\mathrm{a}} \pm 0.238$ & 134.49 & $3.65^{\mathrm{a}} \pm 0.175$ & 97.07 \\
\hline \multicolumn{2}{|l|}{ Control } & $5.74^{\mathrm{b}} \pm 0.310$ & 100.00 & $3.76^{\mathrm{a}} \pm 0.183$ & 100.00 \\
\hline
\end{tabular}

Each value represents the mean of ten replicates.

Values across each column having the same superscript letters were not significantly different $(p>0.05)$. 

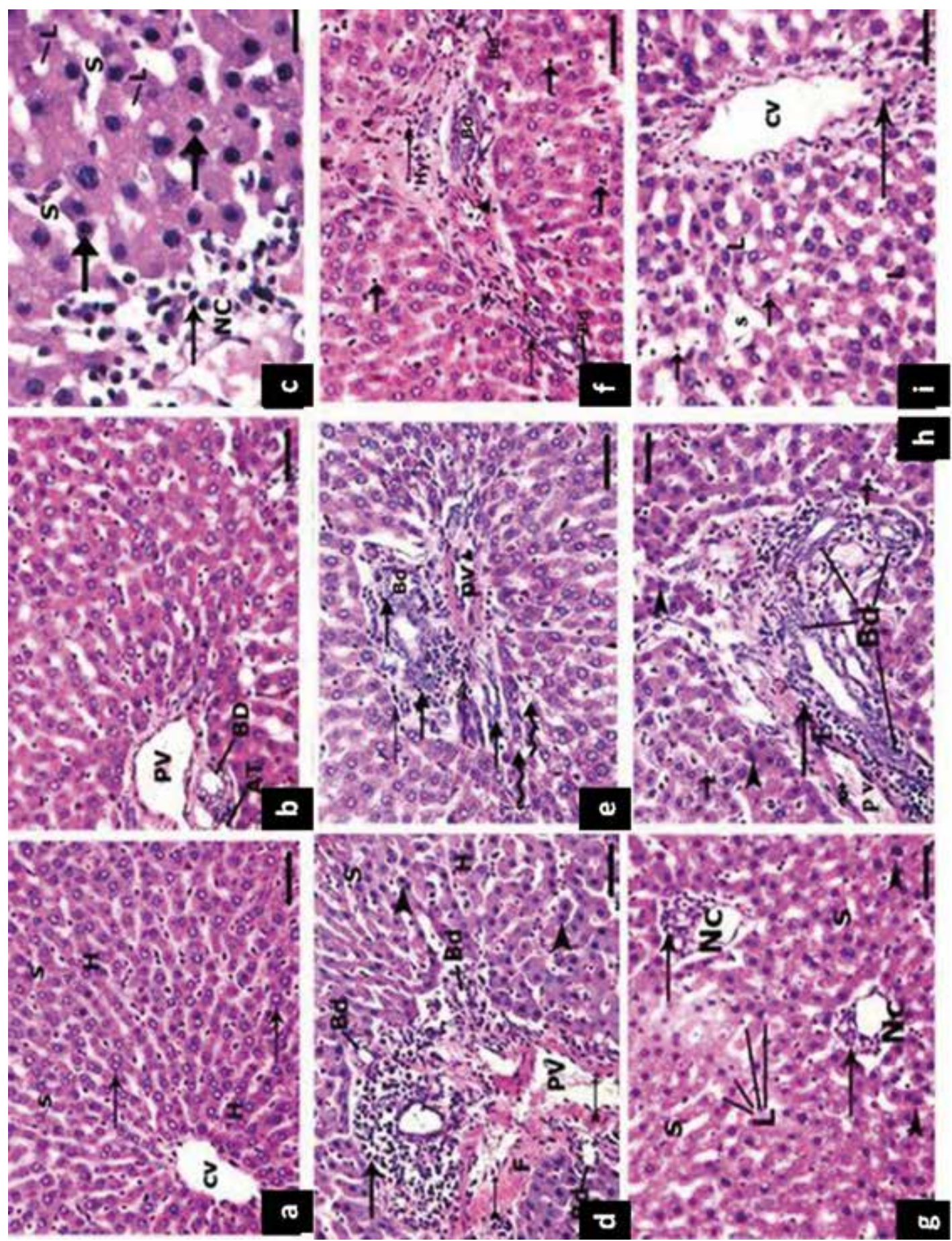

Acta Biologica Hungarica 66, 2015 
Fig. 1. Sections taken from the liver of male rats stained with H\&E. Hepatic tissue of the control rat group showing a) Normal histological architecture of hepatocyte $(\mathrm{H})$ radiating from central vein $(\mathrm{cv})$ with central vesicular nuclei (arrows), the hepatocytes are separated by narrow blood sinusoids (s); b) Portal area between hepatic lobules with a branch of bile ductule (BD), a branch of the portal vein (pv) and hepatic artery (AT); Hepatic tissue of rat treated with malathion (16 ppm) showing c) Focal necrotic area (NC) with inflammatory cells infiltration (thin arrows), dilatation of sinusoids (s), lipid droplets (L) and pyknotic nuclei (thick arrows); d) Inflammatory cells infiltration (thick arrows) in the portal area, newly formed bile ductules $(\mathrm{Bd})$, fibrosis $(\mathrm{F})$ and dilatation of portal vein $(\mathrm{pv})$ with its swelling endothelial cells (thin arrows). Also, pyknotic nuclei (head arrows) and dilatation of sinusoids (s); Hepatic tissue of rat treated with malathion ( $8 \mathrm{ppm}$ ) showing e) Portal area with lymphocyte infiltrations (thin arrow), proliferated bile ductules (thick arrows), swelling endothelia (head arrow) of portal vein (PV) Also, some lipid droplets (irregular arrows); f) Portal area surrounded by hyalinization region (Hy) with inflammatory cells infiltration (thin arrows), newly formed bile ductules (Bd) and swelling endothelia (head arrow) of portal vein. Also, proliferated kupffer cells (thick arrows); Hepatic tissue of rat treated with spinosad (16 $\mathrm{ppm}$ ) showing g) Different foci of necrosis (NC) with inflammatory cells infiltration (thin arrows), dilatation of sinusoids (s), lipid droplets (L) and pyknotic nuclei (head arrows); h) Inflammatory cells infiltration (long arrow) in the portal area, proliferation of bile ductules (Bd), fibrosis (F) and dilatation of portal vein (pv) with its swelling endothelial cells (irregular arrow). Also, pyknotic nuclei (head arrows) and kupffer cells (short arrows); i) Hepatic tissue of rat treated with spinosad (8 ppm) showing hyalinization and thickening wall of the central vein (cv) with inflammatory cells infiltration (long arrow), lipid droplets (L), dilatation of sinusoids (s) and kupffer cells (short arrows). Scale bar $=12.5 \mu \mathrm{m}$ for all photomicrographs except $3(6.25 \mu \mathrm{m})$

histological structure. On the other hand, histopathological damage was found in the liver and kidney of male rats treated with malathion and spinosad in a dose-dependent manner. The observations are summarized in the legends.

\section{DISCUSSION}

The physical observation results of our study agree well with the earlier findings of Rezg et al. [31] which indicated that no signs of toxicity were observed in malathiontreated animals until the end of the experiment. Also, Mansour et al. [24] found that there were no signs of toxicity noted when rats treated with spinosad.

As for PChE activity results, Rustemeijer et al. [33] found an association between PChE activity and the rate of triacylglycerol synthesis. Decreased PChE activity has been found in patients suffering liver dysfunction [1]. PChE activity was positively associated as well with serum concentrations of cholesterol and triglycerides and with measures of overweight, obesity, and body fat distribution [10]. PChE activity pattern was found to be parallel with serum cholesterol and was related with serum albumin in chronic liver diseases [11].

Liver is often the primary target for the toxic effects of xenobiotics. It is known that the detoxification of the toxic materials which enter the body occurs mainly in the liver [3]. Therefore, liver can be used as an index for the toxicity of xenobiotics. Hence, the activities of some enzymes and levels of certain biochemical parameters representing liver function, i.e. AST, ALT, ALP, ACP, total protein, albumin, bilirubin 

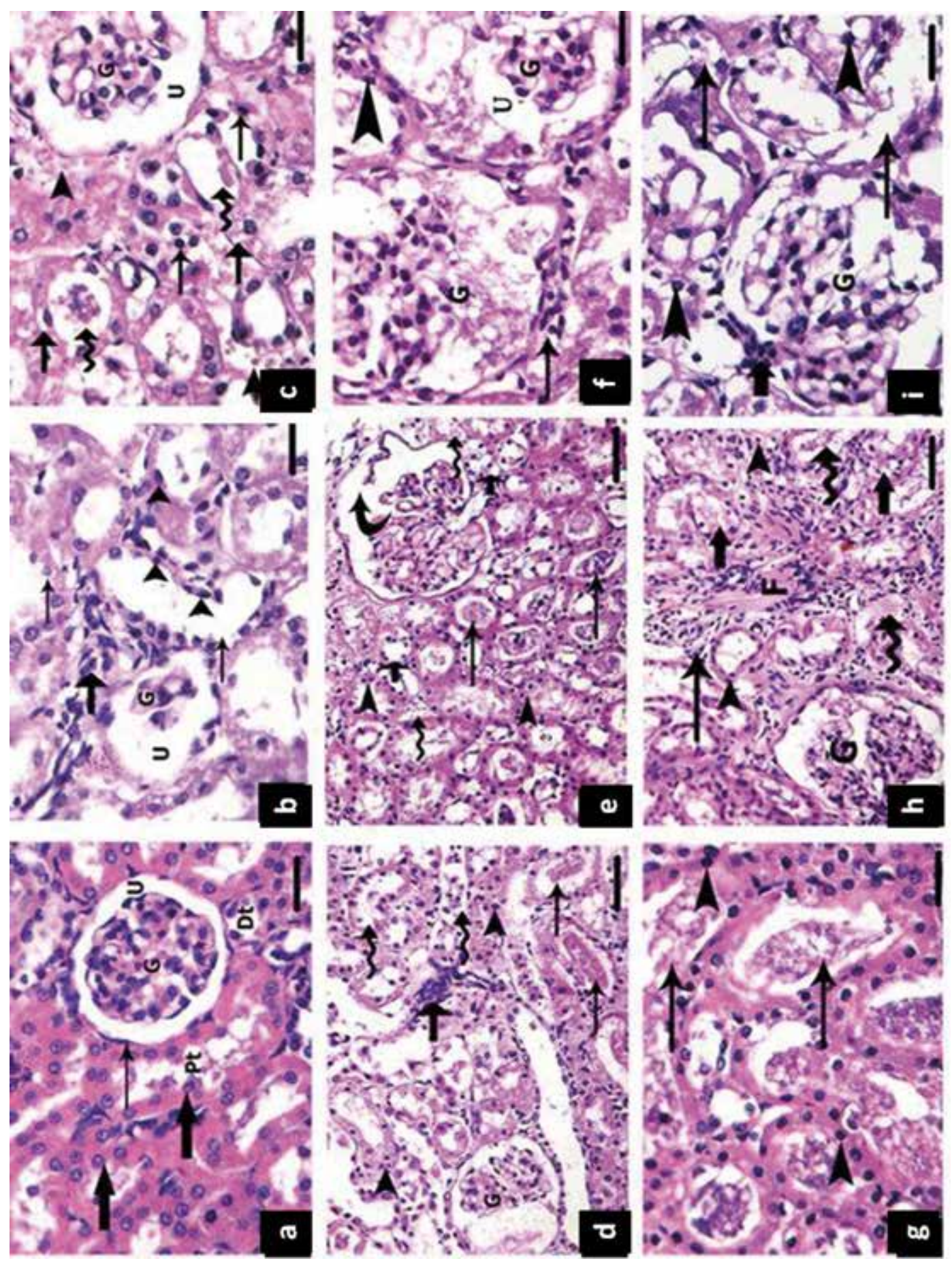
Fig. 2. Sections taken from the kidney of male rats stained with H\&E. a) Renal tissue of the control group showing Malpighian corpuscles with Bowman's capsule (thin arrow), glomerulus $(\mathrm{G})$ and urinary space $(\mathrm{U})$. The proximal tubules (Pt) and distal tubules (Dt) were observed with their vesicular nuclei (thick arrows); Renal tissue of rat treated with malathion (16 ppm) showing b) Shrunken glomeruli (G), widened urinary space $(U)$, inflammatory cells infiltration in the interstitial tissue (thick arrow), focal degenerative changes of proximal tubules (thin arrows) and pyknotic nuclei (head arrows); c) Shrunken glomeruli (G), widened urinary space (U), cytoplasm vacuolation of renal tubules (thick arrows), hyaline material in the lumen of some tubules (irregular arrows) and pyknotic nuclei (thin arrows). Also, dilatation and congestion of blood vessels (head arrows); d) Shrunken glomeruli (G), cytoplasm degeneration of renal tubules (irregular arrows), hyaline material and epithelial casts deposition in the lumen of some tubules (thin arrows) and pyknotic nuclei (head arrows). Also, inflammatory cells infiltration in the interstitial tissue (thick arrow); e) Renal tissue of rat treated with malathion (8 ppm) showing rupture of Bowman's capsule (curved arrow), cytoplasm degeneration of renal tubules (short arrows), hyaline material and epithelial casts deposition in the lumen of some tubules (long arrows) and pyknotic nuclei (head arrows) as well as congested blood vessels (irregular arrow); Renal tissue of rat treated with spinosad (16 ppm) showing f) Enlargement of renal corpuscle with atrophied glomerular tuft $(\mathrm{G})$, widened urinary space (U), pyknotic nuclei (head arrows) and inflammatory cells infiltration (arrow); g) Hyaline material and epithelial casts deposition in the lumen of many tubules (arrows) and pyknotic nuclei (head arrows); h) Deposition of fibres (F) in the intertubular spaces and inflammatory cells infiltration (long arrow). Cytoplasm degeneration of renal tubules (short arrows), hyaline material in the lumen of some tubules (irregular arrows) and pyknotic nuclei (head arrows) as well; i) Renal tissue of rat treated with spinosad (8 ppm) showing enlargement of renal corpuscle with vacuolated glomeruli $(\mathrm{G})$, cytoplasm degeneration of renal tubules (long arrows), pyknotic nuclei (head arrows) and little inflammatory cells infiltration (short arrow). Scale bar $=6.25 \mu \mathrm{m}$ for all photomicrographs except 4,5 and $8(12.5 \mu \mathrm{m})$

and cholesterol were determined in treated and untreated rats. Generally, results of AST and ALT may indicate degeneration changes and hypo function of liver as the effect of malathion and spinosad on the hepatocytes was in the form of tissue damage in which cellular enzymes are released from the cells into the blood serum. In other words, AST and ALT are two hepatic enzymes which will be released in blood in the event of cellular destruction proportionally to the intensity of the cellular aggression [42]. The same explanation was reported by Ncibi et al. [26]. Consequently, these serum enzymes are markers of liver damage [13]. The elevated ACP activity may be associated with the cell disintegration resulting from pesticide treatment, thus suggesting prenecrotic changes in the liver tissues [34]. It has been shown that OP insecticides can elevate the enzymatic activities of AST, ALT, and ALP [27, 16]. Wang et al. [44] have also stated organophosphorus pesticides (OPPs) are generally toxic to mammals, however, the toxicity to other organisms and their potential interactive effects still remain unclear. Albumin, which is the most abundant blood plasma protein, is produced by the liver and study has shown that its production can be decreased by OPPs such as chlorpyrifos [27]. Since reductions in albumin levels are generally suggestive of liver disease, it is possible that OPPs like malathion alter protein and free amino acid metabolism and their synthesis in the liver [26]. Qualitative and quantitative disturbance of protein synthesis is a consequence of impaired hepatic function [6]. Hypoalbuminemia is a liver disorder thought to be a consequence of decreased hepatic synthesis of albumin [5]. OPPs generally increase the total choles- 
terol and total lipid levels [22], and indeed, in the present study, malathion elevated the total cholesterol levels in rats treated with its higher concentration. This increase in serum cholesterol can be attributed to the effect of pesticides on the permeability of the liver cell membrane [46]. In addition, the increase in serum total cholesterol levels may be due to the blockage of the liver bile ducts, which reduces or stops cholesterol secretion into the duodenum [27]. Several OPPs were reported to induce hyperglycemia in mammals [29], activating glycogenolysis and gluconeogenesis and interfering with energy metabolism as well as with several organs and systems [32]. Lasram et al. [22] reported that malathion induced dyslipidemia might result in insulin resistance and hyperglycemia which might contribute to the increased incidence of diabetes all over the world. Few studies conducted on oral ingestion of OPPs have shown hyperglycemia in animals [29]. The cause for hyperglycemia has been attributed to the effect of malathion on the production of free radicals and oxidative damage to pancreas $[15,37]$. Spinosad exhibits low mammalian toxicity and a highly favorable environmental profile [9], thus approved for use in organic agriculture by numerous international certification programs [7]. However, increasing number of studies has showed that blockage of the liver bile ducts, which reduces or stops cholesterol secretion into the duodenum [45, 24]. Male and/or female rats given 0.1 or $0.2 \%$ spinosad had increases in AST, ALT, and ALP activities [45]. In this study, spinosad had no effect on glycemic levels. This result indicates that there is no interference of spinosad with the regulatory mechanisms of carbohydrates reserves in rats.

Concerning renal function parameters, the above mentioned findings are in accordance with those reported by Farghaly and El-Maghraby [16] who found that the level of serum urea was significantly increased in fenitrothion treated mice. Urea increased in male and/or female rats given 0.1 or $0.2 \%$ spinosad [45]. Urea and creatinine are useful in early deduction of nephrotoxicity induced by exogenous compounds. These parameters are used as index of renal damage in living organisms [9]. Elevation of urea and creatinine concentration in serum of treated male albino rats may be attributed to reduction in glomerular filtration in the kidney and also reflect dysfunction of the kidney tubules [43].

With reference to relative weights of male albino rat's liver and kidney, the elevation in liver weights has been reported in previous investigations [4]. Explanation of liver enlargement could be due to the accumulation of abnormal amounts of fat, predominately triglyceride, in the parenchymal cells. Triglyceride accumulation is a result of an imbalance between the rate of synthesis and the rate of release of triglyceride by the parenchymal cells into the systemic circulation [28]. There were no treatment-related differences in renal body weights between control and spinosadtreated $(10 \mathrm{mg} / \mathrm{kg} /$ day $)$ dams rats and rabbits [4].

Regarding histopathological changes in the liver and kidney, El-Banhawy et al. [15] found a remarkable abundance of lymphocyte infiltration in the liver tissues post-xenobiotic administration, and postulated that such changes were a prominent response of body tissues facing any injurious impacts. Many reports had elucidated that hepatocellular damage could be correlated with the disturbed enzyme activities. In this respect, Martin et al. [25] reported that liver tissues which are known for their 
rich contents of aminotransferases (AST \& ALT) suffer markedly from their loss under many pathological conditions. Thus, the biochemical parameter data obtained from this study support this speculation in which malathion- and spinosad-treated rats showed alteration in the activities of AST and ALT. Histopathological lesions have been widely used as biomarkers for the health evaluation of organisms exposed to pollutants [30]. Histopathological biomarker in environmental monitoring is of significant advantage as it permits examining specific target organs which are responsible for vital functions. Moreover, the changes noticed in these vital organs are usually easier to identify as compared to functional ones and can be used as warning symptoms for organism health. Histological examinations of the hepatic tissues of malathion-exposed rats revealed degenerative changes in the liver in the form of parenchymatous degeneration [31]. OPPs are known to induce various histopathological changes in the liver tissues [17, 36]. OPPs have been also shown to induce hemorrhage, inflammatory cell infiltration, tissue damage, and necrosis [21]. Such liver damage may arise from the toxic effects of malathion, which disturbs the detoxification mechanisms of the liver. Similar findings to the current observations were reported earlier [30] in kidney tissue of rats administered with chlorpyrifos. The most notable effect of spinosad after subchronic exposure in rats is vacuolar degeneration [19]. Stebbins et al. [38] found that mice given $0.015 \%$ spinosad had vacuolation in liver and kidney tissues. In addition, it is possible that malathion and spinosad, like several other insecticides, adversely affect the cytochrome P450 system or the mitochondrial membrane transport system of hepatocytes [17].

\section{CONCLUSIONS}

In the light of the aforementioned results, it can be seen that biochemical parameters are in coincidence with histopathological observations which showed degenerative changes in liver and kidney of treated rats with malathion and spinosad in a doserelated manner. Moreover, a low concentration of malathion caused histopathological alterations in the liver and kidney of rats. Thus, more attention is needed to limit the use of malathion, which is widely used in the developing countries. Furthermore, such results may highlight the necessity of further investigations to evaluate the toxic hazards of spinosad at very low doses for non-target organisms.

\section{ACKNOWLEDGEMENTS}

The author would like to thank the members of Research Support Fund, Scientific Research Administration, Research and Graduate Studies Sector, Kafr El-Sheikh University for providing adequate funding and facilities to carry out this research work. 


\section{REFERENCES}

1. Ali, N., Hoque, M. A., Haque, A., Salam, K. A., Karim, M. R., Rahman, A., Islam, K., Saud, Z. A., Khalek, M. A., Akhand, A. A., Hossain, M., Mandal, A., Karim, M. R., Miyataka, H., Himeno, S., Hossain, K. (2010) Association between arsenic exposure and plasma cholinesterase activity: a population based study in Bangladesh. Environ. Health 9, 1-9.

2. Assie, L. K., Francis, F., Gengler, N., Haubruge, E. (2007) Response and genetic analysis of malathion-specific resistant Tribolium castaneum (Herbst) in relation to population density. J. Stored Prod. Res. 43, 33-44.

3. Balistreri, W. F., Shaw, L. M. (1987) Liver function. In: Tietz, N. B. (ed.) Fundamentals of Clinical Chemistry. 3rd ed. Saunders Company Philadelphia, London, Toronto, pp. 729-761.

4. Breslin, W. J., Marty, M. S., Vedula, U. V., Liberacki, A. B., Yano, B. L. (2000) Developmental toxicity of Spinosad administered by gavage to CD1 rats and New Zealand white rabbits. Food Chem. Toxicol. 38, 1103-1112.

5. Burtis, C., Edward, A. (1994) Clinical Chemistry. 2nd ed. Vol. 2. Saunders Company, Philadelphia, London, Toronto.

6. Celia, M. H., Wilkinson, J. S. (1973) Liver function. Aust. Vet. J. 49, 163-169.

7. Cleveland, C. (2007) Environmental and health assessments for spinosad against the backdrop of organic certification. In: Felsot, A. J., Racke, K. D. (eds) Certified Organic and Biologically-Derived Pesticides: Environmental, Health, and Efficacy Assessment. American Chemical Society Symposium Series, Washington, D.C., pp. 109-130.

8. Cleveland, C. B., Mayes, M. A., Cryer, S. A. (2001) An ecological risk assessment for spinosad use on cotton. Pest. Manag. Sci. 58, 70-84.

9. Coles, E. H. (1986) Veterinary Clinical Pathology. 4th ed. W.B. Saunders Company, Philadelphia, London, Toronto, Mexico City, Hong Kong, pp. 171-199.

10. Das, U. N. (2012) Acetylcholinesterase and butyrylcholinesterase as markers of low-grade systemic inflammation. Ann. Hepatol. 11, 409-411.

11. Davis, L., Britten, J. J., Morgan, M. (1997) Cholinesterase: its significance in anaesthetic practice. Anaesthesia 52, 244-260.

12. Ecobichon, D. J. (2001) Toxic effects of pesticides. In: Klaassen, C. D. (ed.) Casarett and Doull's Toxicology. 5th ed. McGraw Hill, New York, pp. 643-690.

13. Eissa, F. I., Zidan, N. A. (2010) Haematological, biochemical and histopathological alterations induced by abamectin and bacillus thuringiensis in male albino rats. Acta Biol. Hung. 61, 33-44.

14. Eissa, F. I., Zidan, N. A., Hashem, M. Y., Ahmed, S. S. (2014) Insecticidal efficacy of certain bioinsecticides, diatomaceous earth and modified atmospheres against Rhyzopertha dominica (F.) (Coleoptera: Bostrichidae) on stored wheat. J. Stored Prod. Res. 57, 30-35.

15. El-Banhawy, M. A., Sanad, S. M., Sakr, S. A., El-Elaimy, I. A., Mahran, H. A. (1993) Histopathological studies on the effect of the anticoagulant rodenticide "Brodifacoum" on the liver of rat. J. Egypt. Ger. Soc. Zool. 12, 185-227.

16. Farghaly, M., El-Maghraby, S. (2009) Investigation of chronic toxicity of 14 C-fenitrothion and its degradation products on stored soybeans. Environ. Toxicol. Pharmacol. 27, 1-6.

17. Gokcime, A., Gulle, K., Demiri, H., Bayra, D., Kocak, A., Altunta, I. (2007) Effects of diazinon at different doses on rat liver and pancreas tissues. Pestic. Biochem. Phys. 87, 103-108.

18. Gozek, K., Artiran, F. (1990) Fate and showed non-significant effect on the activity of the magnitude of malathion residues in stored maize and enzyme bean seeds. In: Proceedings of the Final Research Co-ordination Meeting. Panel Proceedings Series (IAEA). Research Co-ordination Meeting on Isotopic Tracer Aided Studies of Pesticide Residues in Stored Products, Ankara (Turkey), 30 May3 Jun 1988./ Joint FAO/IAEA Div. of Nuclear Techniques in Food and Agriculture, Vienna (Austria), pp. $45-55$.

19. Grothe, D. W., Boss, S. M., Gries, C. L. (1992) A subchronic toxicity study in CD-1 mice administered XDE-105 in the diet for 3 months. Unpublished Report No. M01290 from Toxicology Research 
Laboratories, Lilly Research Laboratories, USA. Submitted for publication to WHO by Dow AgroSciences, Letcombe, United Kingdom.

20. Grube, A., Donaldson, D., Kiely, T., Wu, L. (2011) Pesticides Industry Sales and Usage: 2006 and 2007 Market Estimates. U.S. Environmental Protection Agency, Washington, D.C.

21. Kalender, Y., Uzunhisarcikli, M., Ogutcu, A., Acikgoz, F., Kalender, S. (2006) Effects of diazinon on pseudocholinesterase activity and haematological indices in rats: the protective role of vitamin E. Environ. Toxicol. Pharmacol. 22, 46-51.

22. Lasram, M. M., Annabi, A. B., Elj, N., Selmi, S., Kamoun, A., El-Fazaa, S., Gharbi, N. (2009) Metabolic disorders of acute exposure to malathion in adult Wistar rats. J. Hazard. Mater. 163, $1052-1055$.

23. Lillie, R. D., Fullmen, H. M. (1976) Histopathologic Technique and Practical Histochemistry. McGraw-Hill, New York, London.

24. Mansour, S. A., Mossa, A. H., Heikal, T. M. (2007) Haematoxicity of a new natural insecticide "spinosad" on male albino rats. Int. J. Agric. Biol. 9, 342-346.

25. Martin, D. W., Mayes, P. A., Rodwell, V. W. (1983) Harper's Review of Biochemistry. Middle East Edition, California.

26. Ncibi, S., Othman, M. B., Akacha, A., Krifi, M. N., Zourgi, L. (2008) Opuntia ficus indica extract protects against chlorpyrifos-induced damage on mice liver. Food Chem. Toxicol. 46, 797-802.

27. Ogutcu, A., Suludere, Z., Kalender, Y. (2008) Dichlorvos-induced hepatotoxicity in rats and the protective effects of vitamins C and E. Environ. Toxicol. Pharmacol. 26, 355-361.

28. Plaa, G. L. (1975) Toxic responses of the liver. In: Casarett, J., Doull, C. (eds) Toxicology, the Basic Science of Poisons. Macmillan Publishing Co. Inc, New York, Chapter 10.

29. Rahimi, R., Abdollahi, M. (2007) A review on the mechanisms involved in hyperglycemia induced by organophosphorus pesticides. Pestic. Biochem. Physiol. 88, 115-121.

30. Rekha, Raina, S., Hamid, S. (2013) Histopathological effects of pesticide-cholopyrifos on kidney in albino rats. Int. J. Res. Med. Sci. 1, 465-475.

31. Rezg, R., Mornagui, B., El-Fazaa, S., Gharbi, N. (2008) Biochemical evaluation of hepatic damage in subchronic exposure to malathion in rats: effect on superoxide dismutase and catalase activities using native PAGE. C. R. Biologies 331, 655-662.

32. Rezg, R., Mornagui, B., Kamoun, A., El-Fazaa, S., Gharbi, N. (2007) Effect of subchronic exposure to malathion on metabolic parameters in the rat. C. R. Biologies 330, 143-147.

33. Rustemeijer, C., Schouten, J. A., Voerman, H. J., Beynen, A. C., Donker, A. J., Heine, R. J. (2001) Is seudocholinesterase activity related to markers of triacylglycerol synthesis in Type II diabetes mellitus? Clin. Sci. (Lond.) 101, 29-35.

34. Saigal, S., Bhatnagar, V. K., Malviys, A. N. (1982) Effect of selected pesticides on alkaline and acid phosphatase in rat. Toxicol. Lett. 12, 177.

35. Salgado, V. L., Sheets, J. J., Watson, G. B., Schmidt, A. L. (1998) Studies on the mode of action of spinosad: the internal effective concentration and the concentration dependence on neural excitation. Pestic. Biochem. Physiol. 160, 103-110.

36. Sayım, F. (2007) Dimethoate-induced biochemical and histopathological changes in the liver of rats. Exp. Toxicol. Pathol. 59, 237-243.

37. Shadnia, S., Ashrafivand, S., Mostafalou, S., Abdollahi, M. (2011) N-acetylcysteine a novel treatment for acute human organophosphate poisoning. Int. J. Pharmacol. 7, 732-735.

38. Stebbins, K. E., Bond, D. M., Novilla, M. N., Reasor, M. J. (2002) Spinosad insecticide: subchronic and chronic toxicity and lack of carcinogenicity in CD-1 mice. Toxicol. Sci. 65, 276-287.

39. Subramanyam, B. H. (2006) Performance of spinosad as a stored grain protectant. In: Lorini, I., Bacaltchuk, B., Beckel, H., Deckers, D., Sundfeld, E., dos Santos, J. P., Biagi, J. D., Celaro, J. C., Faroni, L. R. D’A., Bortolini, L. de O. F., Sartori, M. R., Elias, M. C., Guedes, R. N. C., da Fonseca, R. G., Scussel, V. M. (eds) Proceedings of the 9th International Working Conference on Stored Product Protection, 15-18 October 2006, Campinas, São Paulo, Brazil. Brazilian Post Harvest Association, Campinas, Brazil, pp. 250-257. 
40. Thompson, G. D., Michel, K. H., Yao, R. C., Mynderse, J. S., Mosburg, C. T., Worden, T. V., Chio, E. H., Sparks, T. C., Hutchins, S. H. (1997) The discovery of Saccharopolyspora spinosa and a new class of insect control products. Down Earth 52, 1-5.

41. Vayias, B. J., Athannassiou, C. G., Milonas, D. N., Mavrotas, C. (2010) Persistence and efficacy of spinosad on wheat, maize and barley grains against four major stored product pests. Crop Prot. 29, 496-505.

42. Vinogradova, L. F., Mirzoian, Zh. A., Kharlitskaia, E. V., Beketova, T. P. (1989) Experimental antioxidant therapy in toxic liver damage from CCl4 and chloxyl. Patol. Fiziol. Eksp. Ter. 4, 52-56.

43. Walmsley, R. N., White, G. H. (1994) A Guide to Diagnostic Clinical Chemistry. 3rd ed. Oxford Blackwell Scientific Publication, London, Edinburgh, Boston.

44. Wang, H. P., Liang, Y. J., Long, D. X., Chen, J. X., Hou, W. Y., Wu, Y. J. (2009) Metabolic profiles of serum from rats after subchronic exposure to chlorpyrifos and carbaryl. Chem. Res. Toxicol. 22, 1026-1033.

45. Yano, B. L., Bond, D. M., Novilla, M. N., McFadden, L. G., Reasor, M. J. (2002) Spinosad insecticide: subchronic and chronic toxicity and lack of carcinogenicity in Fischer 344 rats. Toxicol. Sci. 65 , 288-298.

46. Yousef, M. I., Awad, T. I., Mohamed, E. H. (2006) Deltamethrin-induced oxidative damage and biochemical alterations in rat and its attenuation by vitamin E. Toxicology 227, 240-247.

47. Zidan, N. A. (2013) Insecticidal effectiveness of certain bio-insecticides, inert dusts and modified atmospheres against Sitophilus oryzae (L.) (Coleoptera: Curculionidae) on stored wheat. Acta Phytopathol. Entomol. Hung. 48, 165-176.

48. Zidan, N. A. (2014) Insecticidal efficacy of spinosad, Beauveria bassiana and Metarhizium anisopliae in combination with diatomaceous earth, for controlling Sitophilus oryzae (L.) (Coleoptera: Curculionidae) infesting stored wheat. Acta Phytopathol. Entomol. Hung. 49, 117-128.

49. Zidan, N. A., Galal, O. A. (2012) Evaluation of hematological, cytogenetical and biochemical effects of malathion and spinosad on male albino rats. Am.-Eurasian J. Toxicol. Sci. 4, 118-130. 